\title{
Comparing The Viral Load of Severe Acute Respiratory Syndrome Coronavirus 2 in Different Human Specimens
}

\author{
Ali Hattem Hussain \\ Nursing Departmen \\ Technical College of Health \\ Sulaimani Polytechnic University \\ Sulaimani, Iraq \\ ali.hussain@spu.edu.iq
}

\begin{tabular}{l}
\hline \hline Article Info \\
\hline Special Issue on \\
Coronavirus (COVID-19) \\
DOI: \\
10.24017/covid.15 \\
Article history: \\
Received:29 May 2020 \\
Accepted:5 June 2020 \\
\hline
\end{tabular}

Keywords:

SARS-COV-2,

Viral load, specimen, nasopharyngeal swab, cycle threshold.

\begin{abstract}
This meta-analysis study analyzed the data of 47 recent studies with data related SARS-COV-2 viral load detection in different human specimens. 1099 patients were tested for SARS-COV-2 viral load using up to 19 different respiratory and non-respiratory specimens using RT-PCR by targeting different types of viral genes of which ORF1ab is the most commonly used target gene. 9909 specimens were taken from the patients. The mean of viral load cycle threshold value is $17.8( \pm 11.7)$, with a median of 15.95 with minimum value of 2.5 and a maximum value of 39.5 . Nasopharyngeal swab has the highest positivity rate (90.5\%) for viral load detection followed by Bronchoalveolar lavage, nasal swab, nasopharyngeal aspirate, throat swab, and then sputum. For the non-respiratory specimen, stool and rectal swab are most appropriate specimens followed by blood. The urine is not appropriate specimen for viral load detection due to very low sensitivity. The sputum was positive up to 23 days in a daily manner since start of symptoms except for the days 19, 21, and 23. Three specimens, the nasopharyngeal swab, throat swab, and rectal swab, showed positive RT-PCR results before the appearance of COVID-19 clinical features. Possible positive results can be detected up to 43 days in throat swab, stool, and rectal swab. After negative conversion of respiratory specimens, the viral shedding can continue more than one month from stool and rectal swab. The 3rd day since onset of symptoms is the most day of testing (223/2935). The highest positivity of SARS-COV-2 viral load was recorded in day 16 since the onset of symptoms.
\end{abstract}

Copyright $@ 2020$ Kurdistan Journal of Applied Research. All rights reserved. 


\section{INTRODUCTION}

Severe Acute Respiratory Syndrome Coronavirus 2 is abbreviated as SARS-CoV-2 and it is called 2019 novel coronavirus $(2019-\mathrm{nCoV})$. It is the causative agent of coronavirus disease (COVID-19), which is also mentioned as 2019 novel coronavirus (2019-nCoV) infection [1].

COVID-19 infection is a respiratory tract infectious disease first reported in Wuhan, China in December 2019 [2], which is quickly, became a pandemic infection causing major global infections with obligatory quarantine period in most of the world [3]. The SARS-CoV-2 virus is a member of coronaviridea family. The virion is enveloped and it contains single stranded, unsegmented, positive sense RNA genome within a nucleocapsid. The virus has a diameter of 80-130 nm. Projections called peplomers or spikes are radiate out from the surface of the virus through envelop and are seen under electron microscope as solar corona giving the name coronaviruses to this family [4].

Any age can acquire the infection; the incubation period of COVID-19 infection is believed to be located within 14 days from the exposure day, few (2.5\%) patients will develop symptoms within 2 days from exposure while the majority (97.5\%) will showed clinical features of respiratory infection after 11 days from exposure [5]. During the incubation period, the patient can transmit the infection to others. The COVID-19 infection has a wide spectrum of clinical presentations ranging from asymptomatic disease to life threating critically ill infection. The patient may develop mild infection with features of upper respiratory tract infection like fever rhinorrhea, sneezing, and mild cough; some patients have diarrhea, and vomiting; the disease may progress to feature of lower respiratory infection including pneumonia like dyspnea and hypoxia then critical complications like respiratory failure and multiorgan dysfunction [6]. For the diagnosis of COVID-19 infection, the suspected cases are confirmed by molecular techniques mostly by real time reverse transcriptase polymerase chain reaction assays to detect SARS-CoV-2 viral RNA in clinical specimens [7].

Respiratory specimens are the most recommended ones, both upper and lower respiratory specimens are collected. For upper respiratory tract specimens, nasopharyngeal swabs and throat (oropharyngeal) swabs are the applied; while for lower respiratory tract specimens' sputum, and if possible, bronchoalveolar lavage and/or tracheal aspirate are used when possible. Although SARS-CoV-2 virus was detected in specimens rather than respiratory ones like stool or serum, the use of this non-respiratory specimen is not recommended for routine molecular diagnosis because the virus dynamics in these specimens is not fully elucidated. Serum might be used for serological diagnosis of SARS-CoV-2 especially when two blood samples taken at acute and convalescent period of infection show increase in antibody titers [8].

Understanding the dynamics of SARS-CoV-2 viral load in different specimens can help in better specimen collection at the appropriate time for confirming the diagnosis and to assess its relation to COVID-19 infection severity. In this aspect, the physicians can categorize the patients for different types of management. Hence, this meta-analysis study was set out to clarify the SARSCoV-2 viral load concentrations measured in different human specimens for comprehensive understanding of viral dynamics, and to better choosing of human specimens whether respiratory or non-respiratory specimens for the diagnosis, management, and follow up of patients infected with SARS-COV-2.

\section{METHODS AND MATERIALS}

Between 29 March 2020 and 7 May of the same year, papers and studies relating to COVID-19 infection were searched in PubMed, EMBASE, Scopus, Cochrane Library, Google Scholar, and Science Direct, figure (1). Papers and studies related to COVID-19 infection were selected using the search key words: COVID-19, SARS-COV-2, viral load, 2019-nCoV, and cycle threshold. The search strategy mentioned in figure (1) was followed. The relevant data were recorded in Microsoft Excel Worksheet, and then data were analyzed using the same Excel Worksheet program and the internet-based Social Science Statistic software program. 


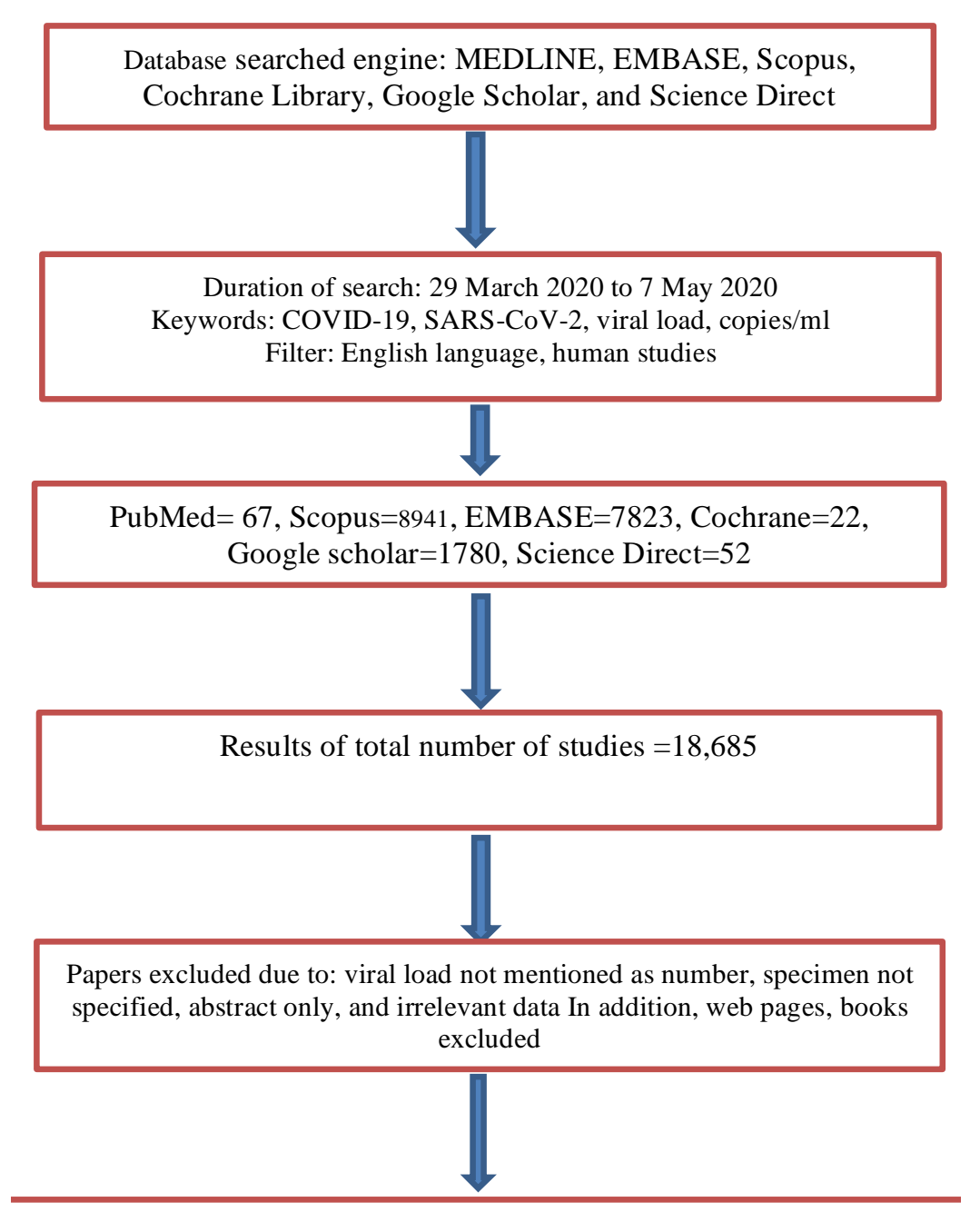

The final number of studies included in this meta-analysis $=47$

Figure 1: Strategy of internet-based search for papers

\section{RESULTS}

In this systematic review, 47 studies, from 11 different countries all over the world, were selected which measured the SARS-CoV-2 viral load in 19 different types of human specimens; the blood specimen was mentioned as serum, plasma, or whole blood. Some studies applied more than one type of specimens for detecting the viral load. According to the number of studies, the top three frequently used specimens, for measuring the viral load, were the nasopharyngeal swab $[\mathrm{n}=29,(61.7 \%)]$, oropharyngeal swab $[\mathrm{n}=26,(55.3 \%)]$, and stool (fecal) specimen $[\mathrm{n}=18$, $(38.3 \%)]$. To a lesser extent, blood or urine were the collected specimens for viral load detection and each of them were used in 13 studies $(27.7 \%)$; the frequency and the percentage of each of the 19 specimens are described in table (1). Among the 19 specimens, ten types were respiratory specimens while the remaining nine were extra-respiratory specimens. Eleven $(61.1 \%)$ of the 
all specimens were collected by noninvasive procedures while eight $(38.9 \%)$ of them are taken by invasive methods.

The total number of patients enrolled in all the 47 studies was 1099 patients of which 9909 specimens were taken from them to detect the viral load. The overall detection rate was $6053 / 9909(61 \%)$. The nasopharyngeal specimen (NPS), oropharyngeal also called throat swab (TS), nasal swab (NS), blood, and stool were the most frequently used specimens, followed by sputum and urine. These seven specimens were the most commonly used specimens for diagnostic purposes, for patients' follow up, and to announce the decision of cure from infection. The SARS-CoV-2 was detected in all of these 19 specimens but with different sensitivities. The viral load detection rate was most frequently recorded in NPS specimens [ $n=1695 / 1873$, $(90.5 \%)$ ] followed by bronchioalveolar lavage (BAL) [n=16/18 (88.9\%)]; while the least detection rate was noted in semen (zero \%), the tears $1 \%$, whereas urine $(2.7 \%)$; the detection rate was not recorded for throat aspirate, lung tissue, and peritoneal swab, as described in table 2.

At least 15 different genes were the targets for detection and measuring the viral load of SARSCoV-2 in different specimens (table 2); most of these genes $(n=11)$ were targeted in NPS followed by throat swab $(n=6)$, then nasal swab, stool, sputum, and urine, and for each of them five different target genes were looked for. In each single study, 1-3 genes were targeted. The $O R F l a b$ and $R d R p$ genes were the most commonly targeted genes for detection of SARS-CoV2; each of them was used for detection of the virus in 9 human specimens followed by $N$ and $E$ genes which were detected in 8 specimens. While, RdRp-IPI,S, M, 5'UTR, and $H$, genes were targeted in 5, 4, 3, 2, and 2 specimens respectively; the last group of genes which were detected in only one specimen are RdRp-P1, RdRp-P2, and RNase P, N1, N2, and N3; table (2).

The quantitative real time reverse transcriptase polymerase chain reaction technique was used for gene detection by measuring the $\mathrm{Ct}$ value. In the vast majority of studies, the $\mathrm{Ct}$ value $\geq 40$ was considered as negative. The exact range of cycle thresholds $(\mathrm{Ct})$ values for viral RNA of SARS-CoV-2 was mentioned for only 12 human specimens (table 2); the highest $\mathrm{Ct}$ values range was 2.5-39 (36.5) and it was mentioned for NPS, while the least was for urine sediment and it was 36.3-36.5 (0.2). The Ct values of SARS-CoV-2. The results showed that NPS and Stool (feces) specimens are containing the highest recorded viral concentrations, and unexpectedly they the specimens that recorded the lowest SARS-CoV-2 concentrations (lowest $\mathrm{Ct}$ values), as shown in table 2. The mean $\mathrm{Ct}$ value is $17.8( \pm 11.7)$, with a median of 15.95 with minimum value of 0.2 and a maximum value of 36.5 .

Table 1: The frequencies and the percentages of the studies applied different clinical specimen for measuring the SARS-CoV-2 viral load [8-54]

\begin{tabular}{|c|c|c|c|c|}
\hline Number & Specimen & $\begin{array}{l}\text { Number of } \\
\text { studies (\%) }\end{array}$ & Reference number & $\begin{array}{c}\text { Type of } \\
\text { procedure }\end{array}$ \\
\hline 1. & $\begin{array}{c}\text { Nasopharyngeal } \\
\text { swab }\end{array}$ & $29(61.7)$ & $\begin{array}{c}{[11],[12],[14],[15],[16],[17],[18],[20],} \\
{[21],[22],[24],[26],[27],[30],[31],[35],} \\
{[36],[37],[39],[40],[41],[42],[44],[46],} \\
{[47],[49],[50],[51],[54]}\end{array}$ & Noninvasive \\
\hline 2. & $\begin{array}{c}\text { Throat } \\
\text { (oropharyngeal) } \\
\text { swab }\end{array}$ & $26(55.3)$ & $\begin{array}{c}\text { [8], [9], [10], [11], [12], [13], [16], [18], } \\
{[19],[20],[22],[29],[32],[34],[36],[38],} \\
{[40],[43],[44],[45],[46],[47],[50],[51],} \\
{[52],[53]}\end{array}$ & Noninvasive \\
\hline
\end{tabular}




\begin{tabular}{|c|c|c|c|c|}
\hline 3. & Sputum & $11(23.4)$ & $\begin{array}{c}{[8],[10],[14],[16],[23],[25],[28],[36],} \\
{[45,[48],[50]}\end{array}$ & Noninvasive \\
\hline 4. & Nasal swab & $6(12.8)$ & [8], [11], [19], [20], [23], [45], [54] & Noninvasive \\
\hline 5. & $\begin{array}{l}\text { Nasopharyngeal } \\
\text { aspirate }\end{array}$ & $2(4.2)$ & [18], [42] & Invasive \\
\hline 6. & Lung tissue & $1(2.1)$ & [46] & Invasive \\
\hline 7. & Pleural fluid & $1(2.1)$ & {$[42]$} & Invasive \\
\hline 8. & $\begin{array}{c}\text { Bronchio-alveolar } \\
\text { lavage }\end{array}$ & $1(2.1)$ & [8] & Invasive \\
\hline 9. & $\begin{array}{l}\text { Fibro- } \\
\text { bronchoscope } \\
\text { brush biopsy }\end{array}$ & $1(2.1)$ & [8] & Invasive \\
\hline 10. & Throat aspirate & $1(2.1)$ & {$[20]$} & Invasive \\
\hline 11. & Stool & $18(38.3)$ & $\begin{array}{c}\text { [8], [9], [10], [12], [14], [15], [16], [17], } \\
{[18],[20],[22],[25],[34],[37],[42],[46],} \\
{[50],[51]}\end{array}$ & Noninvasive \\
\hline 12. & Urine & $13(27.7)$ & $\begin{array}{c}8],[14],[15],[16],[18],[21],[22],[25], \\
{[37],[42],[45],[46],[50]}\end{array}$ & Noninvasive \\
\hline 13. & Saliva & $4(8.5)$ & {$[25],[26],[32],[39]$} & Noninvasive \\
\hline 14. & Rectal swab & $3(6.4)$ & [24], [31], [42] & Noninvasive \\
\hline 15. & Ocular swab & $2(4.2)$ & {$[23],[28]$} & Noninvasive \\
\hline 16. & Semen & $1(2.1)$ & {$[21]$} & Noninvasive \\
\hline 17. & Tears & $1(2.1)$ & {$[30]$} & Noninvasive \\
\hline 18. & $\begin{array}{l}\text { Blood (whole } \\
\text { blood, plasma, } \\
\text { serum ) }\end{array}$ & $13(27.7)$ & $\begin{array}{c}{[8],[15],[16],[18],[19],[25],[33],[37],} \\
{[42,[45],[46],[50],[51]}\end{array}$ & Invasive \\
\hline 19. & Peritoneal swab & $1(2.1)$ & {$[20]$} & Invasive \\
\hline
\end{tabular}

Table 2: The viral load detection rate of SARS-CoV-2 in clinical specimens; cycle threshold range results and the target genes are displayed [8-54]

\begin{tabular}{cccc}
\hline Specimen & Positive rate & Target Gene & Ct range \\
\hline Nasopharyngeal swab & $\begin{array}{c}90.5 \% \\
(1695 / 1873)\end{array}$ & $\begin{array}{c}\text { ORF1ab, N, E, RdRp, H, S, 5'UTR, } \\
\text { N1, N2, N3, RNase P, }\end{array}$ & $2.5-39$ \\
\hline Bronchioalveolar lavage & $88.9 \%(16 / 18)$ & ORF1ab, E, RdRp-IP1, RdRp, & $24.7-36.2$ \\
\hline Nasal swab & $\begin{array}{c}82.1 \% \\
(1261 / 1536)\end{array}$ & ORF1ab, E, RdRp, N, M & $16.62-38.4$ \\
\hline Saliva & $\begin{array}{c}\text { 80.3\% } \\
(232 / 280)\end{array}$ & 5'UTR region, S & $18-35$ \\
\hline
\end{tabular}




\begin{tabular}{|c|c|c|c|}
\hline Nasopharyngeal aspirate & $76.5 \%(52 / 68)$ & RdRp-IP1, RdRp & $\mathrm{NM}$ \\
\hline Throat swab & $\begin{array}{c}74.3 \% \\
(1909 / 2571)\end{array}$ & $\begin{array}{c}\text { ORF1ab, E, RdRp, N, RdRp1, } \\
\text { RdRp2 }\end{array}$ & $18.26-38.6$ \\
\hline Sputum & $\begin{array}{c}56.7 \% \\
(382 / 674)\end{array}$ & ORF1ab, N, M, RdRp, E & $16.1-38.8$ \\
\hline $\begin{array}{c}\text { Fibro bronchoscope brush } \\
\text { biopsy }\end{array}$ & $46.2 \%(6 / 13)$ & ORF1ab, & $26.9-36.8$ \\
\hline Stool & $\begin{array}{c}45.2 \% \\
(397 / 878)\end{array}$ & ORF1ab, RdRp, N, E, RdRp-IP1, & $4.65-39.1$ \\
\hline Ocular secretion & $18.4 \%(7 / 38)$ & $\bar{M}$ & $21.66-36.56$ \\
\hline Rectal swab & $17.9 \%(12 / 67)$ & ORF1ab, N & $22.5-37$ \\
\hline Blood & $\begin{array}{c}6.2 \% \\
(64 / 1025)\end{array}$ & ORF1ab, N, RdRp-IP1, RdRp & $34.1-35.4$ \\
\hline Urine and Urine sediment & $2.7 \%(19 / 710)$ & ORF1ab, N, RdRp, E, S & $36.3-36.5$ \\
\hline Tears & $1 \%(1 / 94)$ & & NM \\
\hline Semen & $0 \%(0 / 1)$ & $\mathrm{E}, \mathrm{S}$ & $\mathrm{NM}$ \\
\hline Throat aspirate & NA & & $\mathrm{NM}$ \\
\hline Peritoneal swab & NA & & $\mathrm{NM}$ \\
\hline Lung tissue & NA & & $\mathrm{NM}$ \\
\hline Pleural fluid & NA & & NM \\
\hline
\end{tabular}

N: nucleocapsid protein; ORF1ab: open reading frame 1ab; RdRp: RNA-dependent RNA polymerase; E: envelope; 5'UTR region: 5' untranslated region; S: spike protein; M: Membrane protein; H: Helicase; RNase P: Ribonuclease P; Ct: cycle threshold, NM: not mentioned.

When distributing the positive results of each specimen according to days since the onset of symptoms, the results revealed that throat swab, stool specimen, and rectal swab could be positive for SARS-CoV-2 up to 42 days in a daily manner since the first day of patient's complaint. The nasopharyngeal swab, blood specimen, and ocular secretions, are daily detecting the virus for, less durations, 30, 28, and 27 days respectively. Day 31 was negative for NPS but the day after was positive. The urine, saliva, and the bronchoalveolar lavage are positive for up to 14,13 , and 10 days respectively and in their $\mathrm{Ct}$ values can be above the threshold in any of these days. Day 16 was also positive for urine sample. The sputum was positive up to 23 days in a daily manner since start of symptoms except for the days 19, 21, and 23 that were negative for the virus. The $\mathrm{Ct}$ values of SARS-CoV-2 in nasal swabs were positive up to 21 days with only one day, day number 19, was negative for the virus; these results are described in table 3 . Three specimens, the nasopharyngeal swab, throat swab, and rectal swab, showed positive RTPCR results before the appearance of COVID-19 clinical features.

Table 3: The positive SARS-CoV-2 viral load in different specimens according to days since the appearance of symptoms; A) days -1 until 21, B) days 22 until 4; Doted squares are specimens with no available data/days

Day since symptoms

$\begin{array}{lllllllllllllllllllllll}-1 & 1 & 2 & 3 & 4 & 5 & 6 & 7 & 8 & 9 & 10 & 11 & 12 & 13 & 14 & 15 & 16 & \mathbf{1 7} & 18 & 19 & 20 & 21\end{array}$




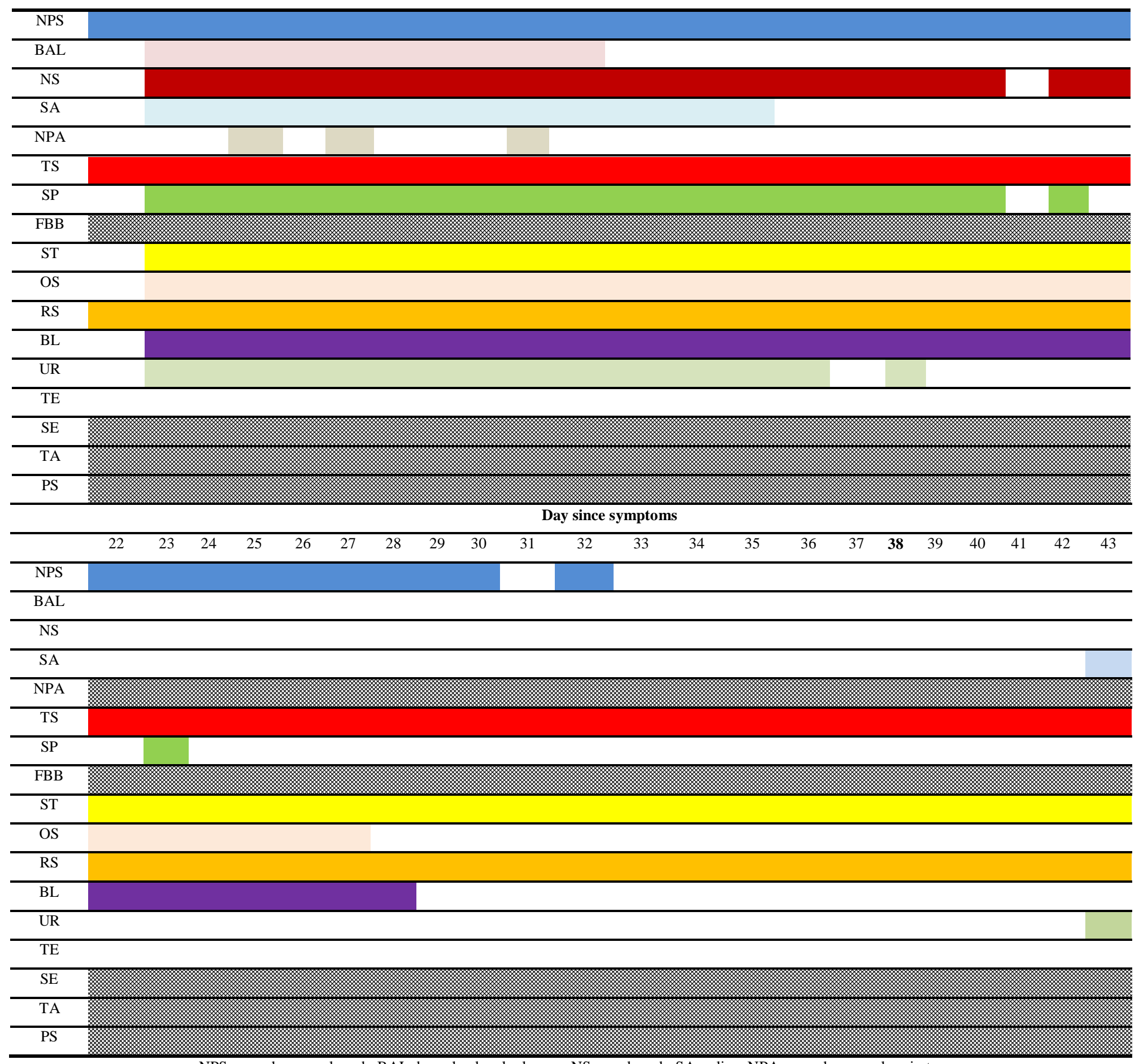

NPS: nasopharyngeal swab; BAL: bronchoalveolar lavage; NS: nasal swab; SA: saliva; NPA: nasopharyngeal aspirate;

TS: throat swab; SP: sputum; FBB: Fibro bronchoscope brush biopsy; ST: stool; OS: ocular secretions; RS: rectal swab;

BL: blood; UR: urine; TE: tears; SE: semen; TA: tracheal aspirate; PS: peritoneal swab; LT: lung tissue

The respiratory specimens are applied for the laboratory diagnosis of COVID-19 infection using

RT-PCR technique to detect SARS-CoV-2; moreover, the cure from infection is also decided

by the same technique for the respiratory specimens. Surprisingly, the shedding of the SARS-

CoV-2 is continuing from the gastrointestinal tract after the confirmed negative conversion of respiratory specimen. This shedding is appearing as positive RT-PCR with Ct values for the 
viral genes above the threshold in rectal swab for 42 days and in stool specimens for 32 days after negative respiratory specimens as nasopharyngeal swab or throat swab, Table (4).

Table 4: Duration of SARS-CoV shedding in non-respiratory specimens after confirmed negative conversion of respiratory samples

\begin{tabular}{cc}
\hline Specimen & $\begin{array}{c}\text { Days after confirmed negative respiratory } \\
\text { specimens }\end{array}$ \\
\hline Stool & 32 \\
\hline Ocular secretion & Not recorded \\
\hline Rectal secretion & 42 \\
\hline Blood & Not recorded \\
\hline Urine & Not recorded \\
\hline Tears & Not recorded \\
\hline Semen & Not recorded \\
\hline Peritoneal fluid & Not recorded
\end{tabular}

The number of tests that is written in the selected papers with regard to the timeline of testing the viral load was 2935 out of 9909 (29.6\%) tested in 43 days from first day of patient's complaint. The $3^{\text {rd }}$ day since onset of symptoms is the most day of testing (223/2935) while the least one of testing specimens were the days 39-42 since appearance of symptoms and for each of these days testing was done only four times (4/2935); table (5). There is gradual increase in positive results since the day of symptom's onset to reach a peak in 16 days after the symptoms, then consistent decline until the day 43; figure (2). The peak of viral load positivity for the most frequently used respiratory and non-respiratory specimens showed that NPS is most frequently recorded as positive for SARS-CoV-2 and this is in the day 16 from start of symptoms. While for throat swab, saliva, sputum, and blood the peak viral load positivity is in the days 7, 5, 13, and 11 post-symptoms' onset respectively. For stool specimen, two days are reported with most positive results, these are days 13 and 15. The rectal swab gave highest positivity in four days, $10,14,16$, and 18; table (6).

Table 5: The cumulative daily-recorded positive and negative RT-PCR results for detecting SARS-

A)

COV-2 RNA viral load; A) days-1 until 21 since onset of symptoms , B) days 22-43

\begin{tabular}{|c|c|c|c|c|c|c|c|c|c|c|c|c|c|c|c|c|c|c|c|c|c|c|}
\hline \multirow{3}{*}{ Specimen } & \multicolumn{22}{|c|}{ Day since symptoms } \\
\hline & -1 & 1 & 2 & 3 & 4 & 5 & 6 & 7 & 8 & 9 & 10 & 11 & 12 & 13 & 14 & $\begin{array}{l}1 \\
5\end{array}$ & 16 & $\begin{array}{l}1 \\
7\end{array}$ & 18 & 19 & 20 & 21 \\
\hline & \multicolumn{22}{|c|}{ The frequency of positive (red numbers) and negative (green numbers) viral load } \\
\hline NPS + & 2 & 17 & 27 & 37 & 25 & 29 & $\begin{array}{l}3 \\
0\end{array}$ & 28 & 31 & 37 & 26 & 37 & 22 & 25 & 23 & $\begin{array}{l}2 \\
1\end{array}$ & 112 & $\begin{array}{l}1 \\
6\end{array}$ & 10 & 19 & 7 & 5 \\
\hline NPS - & & 3 & 1 & 3 & 3 & 7 & 6 & 13 & 7 & 7 & 7 & 22 & 7 & 11 & 8 & $\begin{array}{l}1 \\
0\end{array}$ & 9 & $\begin{array}{l}1 \\
6 \\
\end{array}$ & 7 & 6 & 5 & 5 \\
\hline $\mathrm{BAL}+$ & & 1 & 1 & 1 & 1 & 1 & 1 & 1 & 1 & 1 & 1 & & & & & & & & & & & \\
\hline BAL - & & 0 & 0 & 0 & 0 & 0 & 0 & 0 & 0 & 0 & 0 & & & & & & & & & & & \\
\hline $\begin{array}{c}\text { Nasal } \\
\text { swab + }\end{array}$ & & 1 & 2 & 2 & 4 & 3 & 3 & 4 & 3 & 0 & 2 & 1 & 2 & 1 & 1 & 2 & 1 & 2 & 1 & 0 & 1 & 1 \\
\hline
\end{tabular}




\begin{tabular}{|c|c|c|c|c|c|c|c|c|c|c|c|c|c|c|c|c|c|c|c|c|c|c|}
\hline $\begin{array}{l}\text { Nasal } \\
\text { swab - }\end{array}$ & & 0 & $\mathbf{0}$ & 1 & $\mathbf{0}$ & $\mathbf{0}$ & 1 & 1 & 1 & 1 & 1 & $\mathbf{0}$ & 1 & 1 & 1 & 1 & 1 & 1 & 1 & & 1 & 0 \\
\hline Saliva + & & 1 & 2 & 3 & 4 & 5 & 2 & 1 & 4 & 3 & 2 & 1 & 1 & 1 & & & & & & & & \\
\hline Saliva - & & 1 & 1 & 1 & 1 & 1 & 1 & 2 & 1 & 1 & 1 & 1 & 1 & 1 & & & & & & & & \\
\hline $\mathrm{NPA}+$ & & & 2 & & & 2 & & & & 1 & & & & & & & & & & & & \\
\hline NPA - & & & 0 & & & 0 & & & & 0 & & & & & & & & & & & & \\
\hline $\begin{array}{l}\text { Throat } \\
\text { swab + }\end{array}$ & 5 & 12 & 11 & 22 & 26 & 32 & $\begin{array}{l}3 \\
0\end{array}$ & 36 & 32 & 31 & 29 & 31 & 25 & 25 & 21 & $\begin{array}{l}1 \\
5\end{array}$ & 11 & 9 & 8 & 8 & 5 & 2 \\
\hline $\begin{array}{l}\text { Throat } \\
\text { swab - }\end{array}$ & 0 & 36 & 32 & 28 & 19 & 13 & 5 & 7 & 3 & 8 & 1 & 9 & 3 & 8 & 2 & 6 & 3 & 8 & 3 & 7 & 3 & 6 \\
\hline Sputum + & & 3 & 1 & 5 & 4 & 5 & 5 & 5 & 4 & 5 & 4 & 5 & 2 & 7 & 4 & 3 & 2 & 3 & 1 & 0 & 1 & 0 \\
\hline Sputum - & & 0 & 0 & 0 & 0 & 0 & 0 & 1 & 0 & 2 & 1 & 2 & 2 & 0 & 1 & 1 & 2 & 1 & 1 & 3 & 1 & 1 \\
\hline Stool + & & 3 & 4 & 5 & 6 & 6 & 9 & 14 & 13 & 15 & 18 & 20 & 19 & 23 & 19 & $\begin{array}{l}2 \\
3 \\
\end{array}$ & 21 & $\begin{array}{l}1 \\
7 \\
\end{array}$ & 16 & 17 & 20 & 22 \\
\hline Stool - & & 32 & 32 & 98 & 26 & 28 & $\begin{array}{l}2 \\
4 \\
\end{array}$ & 27 & 19 & 19 & 16 & 16 & 10 & 14 & 7 & 7 & 4 & 7 & 4 & 7 & 3 & 3 \\
\hline $\begin{array}{l}\text { Rectal } \\
\text { swab + }\end{array}$ & 2 & 1 & 3 & 3 & 2 & 2 & 2 & 2 & 4 & 1 & 5 & 1 & 4 & 1 & 5 & 1 & 5 & 1 & 5 & 1 & 4 & 1 \\
\hline $\begin{array}{l}\text { Rectal } \\
\text { swab - }\end{array}$ & 0 & 1 & 0 & 2 & 1 & 3 & 2 & 1 & 2 & & 1 & 1 & 0 & 1 & 0 & 0 & 0 & 0 & 0 & 0 & 0 & 0 \\
\hline $\begin{array}{c}\text { Ocular } \\
\text { secretion } \\
+ \\
\end{array}$ & 1 & 1 & 1 & 1 & 1 & 1 & 1 & 1 & 1 & 1 & 1 & 1 & 1 & 1 & 1 & 1 & 1 & 1 & 1 & 1 & 1 & 1 \\
\hline $\begin{array}{c}\text { Ocular } \\
\text { secretion } \\
- \\
\end{array}$ & 0 & 0 & 0 & 0 & 0 & 0 & 0 & 0 & 0 & 0 & 0 & 0 & 0 & 0 & 0 & 0 & 0 & 0 & 0 & 0 & 0 & 0 \\
\hline Blood & & 1 & 1 & 1 & 1 & 1 & 1 & 2 & 1 & 1 & 1 & 3 & 1 & 2 & 1 & 1 & 1 & 1 & 1 & 1 & 1 & 1 \\
\hline Blood & & 2 & 1 & 5 & 2 & 3 & 1 & 8 & 2 & 8 & 1 & 6 & 1 & 7 & 1 & 2 & 1 & 2 & 1 & 3 & 0 & 2 \\
\hline Urine + & & 1 & 1 & 1 & 1 & 1 & 1 & 1 & 1 & 1 & 1 & 1 & 1 & 1 & 1 & & 1 & 0 & 0 & 0 & 0 & 0 \\
\hline Urine - & & 0 & 4 & 2 & 1 & 5 & 1 & 8 & 2 & 4 & 1 & 4 & 0 & 4 & 0 & 3 & 0 & 3 & 1 & 3 & 1 & 3 \\
\hline Tears + & & & & 0 & 0 & 0 & 0 & 0 & 0 & 0 & 0 & 0 & 0 & 0 & 0 & 0 & 0 & 0 & 0 & 0 & 0 & \\
\hline Tears - & & & & 2 & 1 & 1 & 1 & 1 & 3 & 2 & 2 & 2 & 2 & 2 & 1 & 5 & 3 & 1 & 1 & & 2 & \\
\hline
\end{tabular}

B)

\begin{tabular}{|c|c|c|c|c|c|c|c|c|c|c|c|c|c|c|c|c|c|c|c|c|c|c|}
\hline \multirow{3}{*}{ Specimen } & \multicolumn{22}{|c|}{ Day since symptoms } \\
\hline & 22 & 23 & 24 & 25 & 26 & 27 & $\begin{array}{l}2 \\
8\end{array}$ & 29 & 3 & & 32 & 33 & 34 & 35 & 36 & 37 & 38 & $\begin{array}{l}3 \\
9\end{array}$ & 40 & 41 & 42 & 43 \\
\hline & \multicolumn{22}{|c|}{ The frequency of positive (red numbers) and negative (green numbers) viral load } \\
\hline NPS & 7 & 4 & 5 & 5 & 5 & 4 & 4 & 1 & 1 & & 1 & 0 & & & & & & & & & & \\
\hline NPS & 2 & 7 & 3 & 4 & 1 & 3 & 0 & 2 & 0 & & 0 & 1 & & & & & & & & & & \\
\hline \multicolumn{23}{|l|}{ BAL } \\
\hline \multicolumn{23}{|l|}{$\begin{array}{c}\text { Nasal } \\
\text { swab }\end{array}$} \\
\hline Saliva + & $\mathbf{0}$ & $\mathbf{0}$ & $\mathbf{0}$ & $\mathbf{0}$ & $\mathbf{0}$ & 0 & 0 & $\mathbf{0}$ & 0 & & 0 & 0 & 0 & $\mathbf{0}$ & $\mathbf{0}$ & 0 & $\mathbf{0}$ & 0 & 0 & 0 & $\mathbf{0}$ & 1 \\
\hline
\end{tabular}




\begin{tabular}{|c|c|c|c|c|c|c|c|c|c|c|c|c|c|c|c|c|c|c|c|c|c|c|}
\hline Saliva - & o & 0 & 0 & 0 & 0 & 0 & $\mathbf{0}$ & $\mathbf{0}$ & $\mathbf{0}$ & $\mathbf{0}$ & $\mathbf{0}$ & 0 & $\mathbf{0}$ & 0 & O & $\mathbf{0}$ & 0 & 0 & $\mathbf{0}$ & 0 & 0 & 0 \\
\hline \multicolumn{23}{|l|}{ NPA } \\
\hline $\begin{array}{c}\text { Throat } \\
\text { swab + }\end{array}$ & 1 & 1 & 1 & 1 & 1 & 1 & 1 & 1 & 1 & 1 & 1 & 1 & 1 & 1 & 1 & 1 & 1 & 1 & 1 & 1 & 1 & 1 \\
\hline $\begin{array}{l}\text { Throat } \\
\text { swab - }\end{array}$ & 1 & 5 & 0 & 5 & 0 & 5 & $\mathbf{0}$ & 2 & 1 & 2 & 1 & 2 & 0 & 0 & 0 & 0 & 0 & 0 & 0 & 0 & $\mathbf{0}$ & 0 \\
\hline Sputum + & & 1 & & 0 & 0 & 0 & & & & & & & & & & & & & & & & \\
\hline Sputum - & & 1 & & 2 & 1 & 1 & & & & & & & & & & & & & & & & \\
\hline Stool + & 15 & 16 & 14 & 13 & 11 & 10 & 8 & 9 & 8 & 9 & 6 & 8 & 7 & 7 & 6 & 6 & 6 & 2 & 2 & 2 & 2 & 1 \\
\hline Stool - & 0 & 3 & 0 & 3 & 0 & 3 & 0 & 3 & 0 & 3 & 0 & 3 & 0 & 0 & 0 & 0 & 0 & 0 & 0 & 0 & 0 & 0 \\
\hline $\begin{array}{c}\text { Rectal } \\
\text { swab + }\end{array}$ & 3 & 1 & 3 & 1 & 1 & 1 & 1 & 1 & 1 & 1 & 1 & 1 & 1 & 1 & 1 & 1 & 1 & 1 & 1 & 1 & 1 & 1 \\
\hline $\begin{array}{l}\text { Rectal } \\
\text { swab - }\end{array}$ & 0 & 0 & 0 & 0 & 0 & $\mathbf{0}$ & $\mathbf{0}$ & $\mathbf{0}$ & 0 & 0 & 0 & 0 & 0 & 0 & 0 & 0 & 0 & 0 & O & 0 & $\mathbf{0}$ & 3 \\
\hline $\begin{array}{c}\text { Ocular } \\
\text { secretion } \\
+ \\
\end{array}$ & 1 & 1 & 1 & 1 & 1 & 1 & & & & & & & & & & & & & & & & \\
\hline $\begin{array}{c}\text { Ocular } \\
\text { secretion } \\
- \\
\end{array}$ & 0 & 0 & 0 & 0 & 0 & 0 & & & & & & & & & & & & & & & & \\
\hline Blood + & 1 & 1 & 1 & 1 & 1 & 1 & 1 & & & & & & & & & & & & & & & \\
\hline Blood - & 0 & 0 & 0 & 0 & 0 & 0 & 0 & & & & & & & & & & & & & & & \\
\hline $\begin{array}{c}\text { Urine/ } \\
\text { sediment } \\
+ \\
\end{array}$ & & 0 & $\mathbf{0}$ & 0 & 0 & 0 & & 0 & 0 & $\mathbf{0}$ & & 0 & & & & & & & & & & 1 \\
\hline $\begin{array}{c}\text { Urine/ } \\
\text { sediment } \\
- \\
\end{array}$ & & 3 & $\mathbf{3}$ & 3 & & 3 & & 3 & & 3 & & 3 & & & & & & & & & & 0 \\
\hline Tears & & & & & & & & & & & & & & & & & & & & & & \\
\hline
\end{tabular}

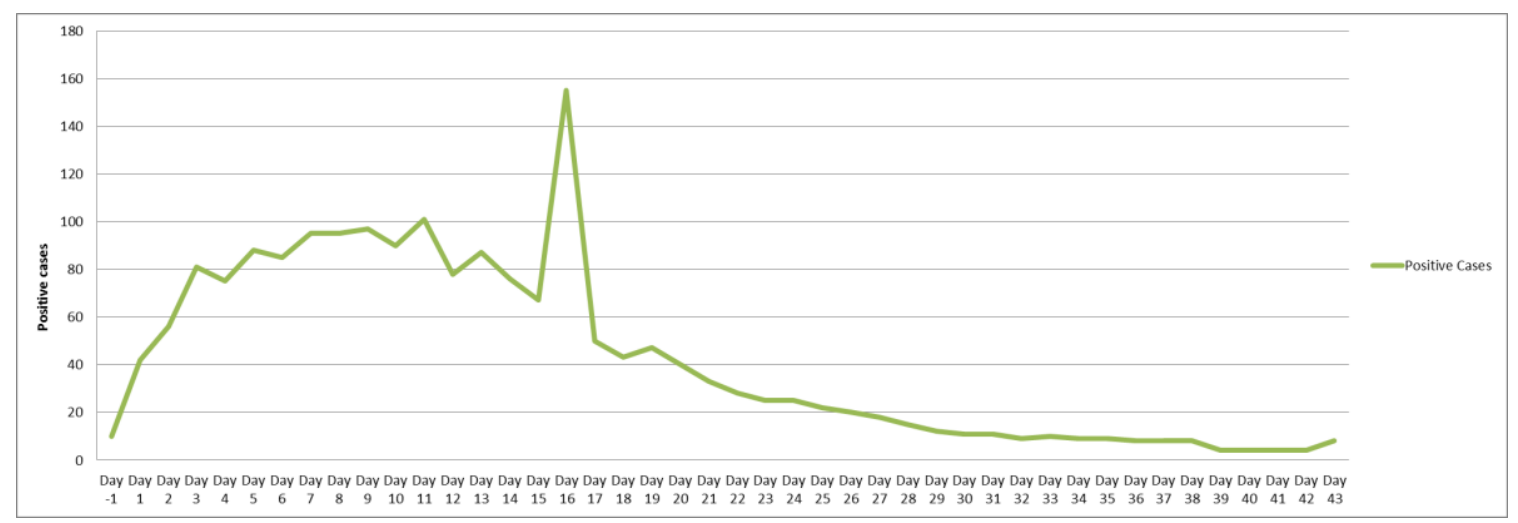

Kurdistan Journal of Applied Research | Special Issue on Coronavirus (COVID-19)| 140 
Figure 2: The chronological distribution of positive RT-PCR results for SARS-COV-2 since one day before symptomatology

Table 6: The peak positive viral load results since the onset of symptoms

\begin{tabular}{cc}
\hline Specimen & The day since onset of symptoms \\
\hline NPS & 16 \\
\hline Throat Swab & 7 \\
\hline Saliva & 5 \\
\hline Sputum & 13 \\
\hline Nasal Swab & 4,7 \\
\hline Stool & 13,15 \\
\hline Rectal Swab & $10,14,16,18$ \\
\hline Blood & 11 \\
\hline
\end{tabular}

\section{DISCUSSION}

In this meta-analysis research, recently published 47 studies about SARS-COV-2 viral infection in different countries all over the world were analyzed for the viral load concentration and viral positivity in different types of human specimens. The total number of patients who were tested was 1099 patients using 9909 specimens from up to 19 types of specimens using periodic laboratory investigation to detect viral load by measuring the $\mathrm{Ct}$ of the targeted gens; the periodic examination explain this large number of specimens collected from the patients with a ratio of 9 tests per patient. The continuous testing of each patient is required to know the clearance of the body from the virus so that to confirm and announce the cure from infection.

NPS was the most commonly used specimen for viral SARS-COV-2 load detection by RT-PCR. This is in accordance to the pervious knowledge that NPS is an appropriate specimen for detecting the respiratory viruses, both molecular and antigen detection as respiratory passages are route of entry and site of viral propagation and route of exit from the body [55]. In addition, SARS-CoV binds to angiotensin-converting enzyme 2 receptors of respiratory epithelium [56]. For these reasons, 9 other different respiratory specimens are used of which throat swab, nasal swab as upper respiratory tract specimens are the most commonly mentioned in the studied enrolled in this meta-analysis; the sputum is the most commonly applied lower respiratory tract specimen.

The NPS reported the highest range of $\mathrm{Ct}$ from very low number of cycles that can cross the threshold and record positivity with very high viral titers to many $\mathrm{Ct}$ with very low viral titer. Low Ct with high viral titer is also recorded in stool, nasal swab, throat swab, sputum, and saliva. These results indicate the possible importance of measuring the viral concentration, not only to diagnose the infection, but also to assess the severity of the condition. The presence of positive viral load in blood samples indicates viremia and a risk marker of possible disease progression and the need for continuous monitoring of the patient until negative conversion and recovery from symptoms is achieved.

Saliva is a good alternative, less annoying specimen than the other upper respiratory specimens with relatively high positivity rate $(80.3 \%)$. This finding increases the suspicion about saliva as a possible route of transmission SARS-COV-2 from infected person to others with the possibility of salivary glands as a reservoir for the virus. Besides, some researchers found that angiotensin-converting enzyme 2 receptors are abundant in oral mucosa [57].

Stool is the most commonly documented non-respiratory specimen for detection of viral load with positivity rate of $45.2 \%$ and this suggest the presence of SARS-COV-2 in the gastrointestinal tract, which is unusual finding for respiratory viruses to present in the gut. The presence of angiotensin-converting enzyme 2 receptors in the gastrointestinal tract makes the intestinal epithelium a target for viral binding and infection [58]. 
Some specimens are not preferred for viral load quantification due to very low sensitivity as in urine, tears, or semen; or due to invasive method of specimen collection as in BAL, fibrobronchoscope brush biopsy, pleural fluid, or lung tissue. The presence of noninvasive and high sensitive methods as NPS, throat swab, nasal swab, sputum, and saliva made the viral load detection by RT-PCR more efficient technique.

This meta-analysis revealed the use of RT-PCR to target more up to 15 different SARS-COV2 genes in different specimens this clarify the efforts to find the most specific and sensitive targets to diagnose this rapidly evolving dangerous respiratory infection. The technique and the target gene are tested by comparing its performance in clinical specimens with tissue cultures approved to propagate the SARS-COV-2 [59].

When distributing the timeline for positive detection of SARS-COV-2, the results revealed daily positivity can be recorded in throat, stool, and rectal swab up to 43 days since the onset of symptoms which signify the importance of these specimens, in addition to NPS, in the diagnosis of SARS-COV-2. This clarifies the need of testing two or more different specimens at the same time for diagnostic purposes; as negative results are also recorded within the same duration.

The positive results are recorded in NPS, throat swab, stool, and rectal swab in different patients one day before the appearance of symptoms and this imply the shedding of virus might be start in incubation period before the appearance of symptoms, which make the control of infection without the presence of effective vaccine a more difficult task. Furthermore, the results showed that viral shedding from gastrointestinal tract with the feces might be continue more than one month after negative conversion of respiratory samples, which increase the modes of viral transmission from cured people to others.

This meta-analysis recorded the peak of viral positivity at 16 days since the start of symptoms; which can help us in timing the specimen collection and better understanding the pathogenesis of COVID-19 infection. However, this peak positivity is different with regard to different samples.

\section{CONCLUSION}

Different respiratory and non-respiratory specimens are used for detection SARS-COV-2 using RT-PCR by targeting different types of viral genes of which ORFlab is the most commonly targeted gene. Nasopharyngeal swab has the highest positivity rate for viral load detection followed by BAL, nasal swab, nasopharyngeal aspirate, throat swab and sputum. For the nonrespiratory specimen, stool and rectal swab are most appropriate specimens for viral detection followed by blood. The urine is not an appropriate specimen for viral load detection due to very low sensitivity. Possible positive results can be present up to 43 days in throat swab, stool, and rectal swab. The viral shedding from stool can continue more than one month from stool and rectal swab. The highest positivity of SARS-COV-2 viral load was recorded in day 16 since the onset of symptoms.

\section{REFERENCE}

[1] C. Lai, P. Shih, C. Ko, J. Tang, R. Hsueh, "Severe acute respiratory syndrome coronavirus 2 (SARS-CoV-2) and coronavirus disease-2019 (COVID-19): The epidemic and the challenges", International Journal of Antimicrobial Agents, Vol. 55, PP. 105924, 2020.

[2] H. Lu, W. Stratton, W. Tang, "Outbreak of pneumonia of unknown etiology in Wuhan China: the mystery and the miracle", Journal of Medical Virology, Vol. 92, no. 4, pp. 401-402, 2020.

[3] T. Singhal, "A Review of Coronavirus Disease-2019 (COVID-19)", Indian Journal of Pediatrics, Vol. 87, no. 4, pp. 281-286, 2020.

[4] H. Li, M. Liu, H. Yu, L. Tang, K. Tang, "Coronavirus disease 2019 (COVID-19): current status and future perspectives", International journal of antimicrobial agents, Vol. 55, no. 5, pp. 105951, 2020.

[5] M. Linton, T. Kobayashi,Y. Yang, "Incubation Period and Other Epidemiological Characteristics of 2019 Novel Coronavirus Infections with Right Truncation: A Statistical Analysis of Publicly Available Case Data" Journal of clinical medicine, vol. 9, no. 2, pp. 538, 2020.

[6] Z. Wu, M. McGoogan, "Characteristics of and Important Lessons From the Coronavirus Disease 2019 (COVID19) Outbreak in China: Summary of a Report of 72314 Cases From the Chinese Center for Disease Control and Prevention", Journal of the American Medical Association, Vol. 323, no. 13, pp. 1239-1242, 2020 
[7] B. Udugama, P. Kadhiresan, N. Kozlowski, A. Malekjahani,, V. Osborne, H. Chen, B. Mubareka S, Gubbay, "Diagnosing COVID-19: The Disease and Tools for Detection", ACS nano, Vol. 14, no. 4, pp. 3822-3835, 2020.

[8] W. Wang, Y Xu, R. Gao, R. Lu, K. Han, G. Wu, W. Tan, "Detection of SARS-CoV-2 in Different Types of Clinical Specimens", Journal of the American Medical Association, Vol. 323, no. 18, pp. 1843-1844, 2020.

[9] Y. Wu, C. Guo, L. Tang, Z. Hong, J. Zhou, X. Dong., L. Kuang, "Prolonged presence of SARS-CoV-2 viral RNA in faecal samples", The lancet Gastroenterology \& hepatology, Vol. 5, no. 5, pp. 434-435, 2020.

[10] Y. Pan, D. Zhang, P. Yang, L. Poon, Q. Wang, "Viral load of SARS-CoV-2 in clinical samples", The Lancet Infectious Diseases, Vol. 20, no. 4, pp. 411-412, 2020.

[11] L. Zou, F. Ruan, M. Huang, L. Liang, H. Huang, Z. Hong, Q. Guo, "SARS-CoV-2 viral load in upper respiratory specimens of infected patients" New England Journal of Medicine, Vol. 382 no. 12, pp. 1177-1179, 2020.

[12] F. Xiao, M. Tang, X. Zheng, Y. Liu, X. Li, H. Shan, "Evidence for gastrointestinal infection of SARS-CoV2. Gastroenterology, Vol. 158, no. 6, pp.1831-1833, 2020.

[13] T. Zhang, X. Cui, X. Zhao, J. Wang, J. Zheng, G. Zheng, Y. Xu, "Detectable SARS-CoV-2 viral RNA in feces of three children during recovery period of COVID-19 pneumonia", Journal of Medical Virology, 2020.

[14] I. Lo, F. Lio, H. Cheong, I. Lei, H. Cheong, X. Zhong, N. Sin, " Evaluation of SARS-CoV-2 RNA shedding in clinical specimens and clinical characteristics of 10 patients with COVID-19 in Macau", International journal of biological sciences, Vol. 16, no. 10, pp. 1698, 2020.

[15] E. Young, X. Ong, S. Kalimuddin, G. Low, Y. Tan, J. Loh, K. Lau, "Epidemiologic features and clinical course of patients infected with SARS-CoV-2 in Singapore", Journal of American Medical Association, Vol. 323, no. 15, pp. 1488-1494, 2020.

[16] Y. Kim, H. Ko, Y. Kim, J. Kim, M. Kim, S. Chung, S. Chin, "Viral load kinetics of SARS-CoV-2 infection in first two patients in Korea", Journal of Korean medical science, Vol. 35, no. 7, 2019.

[17] C. Jones, B. Mühlemann, T. Veith, M. Zuchowski, J. Hofmann, A. Stein, C. Drosten, C, "An analysis of SARSCoV-2 viral load by patient age", German Research network Zoonotic Infectious Diseases, 2020.

[18] F. Chan, Y. Yip, W. To, C. Tang, Y. Wong, H. Leung, Y. Choi, "Improved molecular diagnosis of COVID-19 by the novel, highly sensitive and specific COVID-19-RdRp/Hel real-time reverse transcription-PCR assay validated in vitro and with clinical specimens", Journal of Clinical Microbiology, Vol. 58, no. 5, 2020.

[19] D. Yadav, A. Potdar, L. Choudhary, A. Nyayanit, M. Agrawal, M. Jadhav, S. Cherian, "Full-genome sequences of the first two SARS-CoV-2 viruses from India", Indian Journal of Medical Research, Vol. 151, no. 2, pp. 200, 2020.

[20] G. Seo, G. Lee, J. Kim, H. Baek, M. Choi, B. Ku, S. Lee, S. Jun, D. Park, G. Kim, J. Kim, O. Lee, T. Kim, C. Park, I. Kim," Rapid Detection of COVID-19 Causative Virus (SARS-CoV-2) in Human Nasopharyngeal Swab Specimens Using Field-Effect Transistor-Based Biosensor", ACS Nano, Vol. 14, no. 4, pp. 5135-5142, 2020.

[21] S. Kleiboeker, S. Cowden, J. Grantham, J. Nutt, A. Tyler, A. Berg, M. Altrich, "SARS-CoV-2 Viral load Assessment in Respiratory Samples", Journal of Clinical Virology, pp. 104439, 2020.

[22] Y. Chen, L. Chen, Q. Deng, G. Zhang, K. Wu, L. Ni, J. Yang," The presence of SARS-CoV-2 RNA in the feces of COVID-19 patients", Journal of Medical Virology, 2020.

[23] F. Colavita, D. Lapa, F. Carletti, E. Lalle, L. Bordi, P. Marsella, G. Ippolito, " SARS-CoV-2 isolation from ocular secretions of a patient with COVID-19 in Italy with prolonged viral RNA detection", Annals of Internal Medicine, 2020.

[24] Y. Xu, X. Li, B. Zhu, H. Liang, C. Fang, G. Gong, H. Zhang, "Characteristics of pediatric SARS-CoV-2 infection and potential evidence for persistent fecal viral shedding", Nature medicine, vol. 26, no. 4, pp. 502-505, 2020.

[25] S. Zheng, J. Fan, F. Yu, B. Feng, B. Lou, Q. Zou, W. Chen, "Viral load dynamics and disease severity in patients infected with SARS-CoV-2 in Zhejiang province, China, January-March 2020: retrospective cohort study", British Medical Journal, 369, 2020.

[26] L. Azzi, G. Carcano, F. Gianfagna, P. Grossi, D. Gasperina, A. Genoni, M. Fasano, F. Sessa, L. Tettamanti, F. Carinci, V. Maurino, A. Rossi, A. Tagliabue, A. Baj, "Saliva is a reliable tool to detect SARS-CoV-2", The Journal of infection, Vol. S0163-445, no. 20, pp. 30213-9, 2020.

[27] A. Emily, H. Jessica, H. Meei-L, P. Garrett, T. Scott, L. Pheobe, D. Sean, L. Diana, J. Keith, "Direct rt-qper detection of sars-cov-2 rna from patient nasopharyngeal swabs without an RNA extraction step", medRxiv and bioRxiv, 2020.

[28] J. Xia, J. Tong, M. Liu, Y. Shen, D. Guo, "Evaluation of coronavirus in tears and conjunctival secretions of patients with SARS-CoV-2 infection", Journal of medical virology, Vol. 92, no. 6, pp. 589-594, 2020.

[29] F. Zhou, T. Yu, R. Du, C. Bin, "Clinical course and risk factors for mortality of adult inpatients with COVID-19 in Wuhan, China: a retrospective cohort study", Lancet, Vol. 395, no. 20, 2020.

[30] Y. Jun, E. Anderson, Z. Kang, F. Wang, P. Rao, E. Young, R. Agrawal, "Assessing viral shedding and infectivity of tears in coronavirus disease 2019 (COVID-19) patients", Ophthalmology, 2020.

[31] X. Jiang, M. Luo, Z. Zou, X. Wang, C. Chen, J. Qiu, "Asymptomatic SARS-CoV-2 infected case with viral detection positive in stool but negative in nasopharyngeal samples lasts for 42 days" Journal of Medical Virology, 2020 . 
[32] R. Yang, T. Deng, N. Wu, B. Yang, J. Li, B. Pan, "Persistent viral RNA positivity during recovery period of a patient with SARS-CoV-2 infection", Journal of medical virology, 2020.

[33] X. Chen, B. Zhao, Y. Qu, Y. Chen, J. Xiong, Y. Feng, J. Ding, "Detectable serum SARS-CoV-2 viral load (RNAaemia) is closely associated with drastically elevated interleukin 6 (IL-6) level in critically ill COVID-19 patients", MedRxiv, 2020.

[34] Y. Xing, W. Ni, Q. Wu, W. Li., G. Li, W. Wang, Q. Xing, "Dynamics of fecal SARS-CoV-2 in infected children during the convalescent phase", The Journal of Infection, 2020.

[35] J. Zhang, X. Dong, Y. Cao, D. Yuan, B. Yang, Q. Yan, D. Gao, "Clinical characteristics of 140 patients infected with SARS-CoV-2 in Wuhan, China", Allergy, 2020.

[36] M. Kim, S. Chung, J. Jo, J. Lee, S. Kim, H. Woo, G. Han, "Identification of Coronavirus Isolated from a Patient in Korea with COVID-19", Osong public health and research perspectives, Vol. 11, no. 1, PP. 3, 2020.

[37] Q. Kam, F. Yung, L. Cui, R. Tzer, M. Mak, M. Maiwald, C. Thoon, "A well infant with coronavirus disease 2019 with high viral load", Clinical Infectious Diseases, 2020.

[38] T. Xu, C. Chen, Z. Zhu, M. Cui, C. Chen, H. Dai, Y. Xue, "Clinical features and dynamics of viral load in imported and non-imported patients with COVID-19", International Journal of Infectious Diseases, 2020.

[39] W. To, Y. Tsang, Y. Yip, H. Chan, C. Wu, C. Chan, C. Lung, "Consistent detection of 2019 novel coronavirus in saliva", Clinical Infectious Diseases, 2020.

[40] L. Wang, Y. Duan, W. Zhang, J. Liang, J. Xu, Y. Zhang, H. Li, "Epidemiologic and clinical characteristics of 26 cases of COVID-19 arising from patient-to-patient transmission in Liaocheng, China", Clinical Epidemiology, Vo. 12, pp. 387, 2020.

[41] Y. Xia, j. Wu, L. Liu, H. Xia, B. Jia, X. Huang, "Epidemiological and initial clinical characteristics of patients with family aggregation of COVID-19", Journal of Clinical Virology, pp. 104360, 2020.

[42] X. Lescure, L. Bouadma, D. Nguyen, M. Parisey, H. Wicky, S. Behillil, V. Enouf, "Clinical and virological data of the first cases of COVID-19 in Europe: a case series", The Lancet Infectious Diseases, 2020.

[43] X. He, H. Lau, P. Wu, X. Deng, J. Wang, X. Hao, X. Mo, "Temporal dynamics in viral shedding and transmissibility of COVID-19", Nature medicine, Vol. 26, no. 5, pp. 672-675, 2020.

[44] W. Zhao, L. He, X. Xie, J. Liu, "The Viral Load of 2019 Novel Coronavirus (COVID-19) has the potential to predict the clinical outcomes", Lancet, SSRN 3546047, 2020.

[45] F. Yu, L. Yan, N. Wang, S. Yang, L. Wang, Y. Tang, F. Wang, "Quantitative detection and viral load analysis of SARS-CoV-2 in infected patients", Clinical Infectious Diseases, 2020.

[46] R. Wölfel, M. Corman, W. Guggemos, M. Seilmaier, S. Zange, A. Müller, M. Hoelscher, "Virological assessment of hospitalized patients with COVID-2019", Nature, pp. 1-5, 2020.

[47] X. Marchand-Senécal, R. Kozak, S. Mubareka, N. Salt, B. Gubbay, A. Eshaghi, O. Ozaldin, "Diagnosis and Management of First Case of COVID-19 in Canada: Lessons applied from SARS", Clinical Infectious Diseases, 2020.

[48] J. Lim, S. Jeon, Y. Shin, J. Kim, M. Seong, J. Lee, J. Park, S. J, "Case of the index patient who caused tertiary transmission of COVID-19 infection in Korea: the application of lopinavir/ritonavir for the treatment of COVID19 infected pneumonia monitored by quantitative RT-PCR", Journal of Korean medical science, Vol. 35, no. 6, 2020.

[49] Y. Lee, W. Li, P. Tsai, L. Chen, S. Syue, C. Li, .C. Ko, "A case of COVID-19 and pneumonia returning from Macau in Taiwan: Clinical course and anti-SARS-CoV-2 IgG dynamic", Journal of Microbiology, Immunology and Infection", 2020.

[50] A. Kujawski, K. Wong, P. Collins, L. Epstein, E. Killerby, M. Midgley, N. Anderson, "First 12 patients with coronavirus disease 2019 (COVID-19) in the United States", MedRxiv, 2020.

[51] L. Holshue, C. DeBolt, S. Lindquist, H. Lofy, J. Wiesman, H. Bruce, G. Diaz, "First case of 2019 novel coronavirus in the United States", New England Journal of Medicine, 2020.

[52] D. Chen, W. Xu, Z. Lei, Z. Huang, J. Liu, Z. Gao, L. Peng, "Recurrence of positive SARS-CoV-2 RNA in COVID19: A case report", International Journal of Infectious Diseases, 2020.

[53] D. Wang, B. Hu, C. Hu, F. Zhu, X. Liu, J. Zhang, Y. Zhao, "Clinical characteristics of 138 hospitalized patients with 2019 novel coronavirus-infected pneumonia in Wuhan, China", Journal of the American Medical Association, Vol. 323, no. 11, pp. 1061-1069, 2020.

[54] J. Guan, Y. Ni, Y. Hu, H. Liang, Q. Ou, X. He, B. Du, "Clinical characteristics of coronavirus disease 2019 in China", New England journal of medicine, Vol. 382, no. 18, pp. 1708-1720, 2020.

[55] J. Meerhoff, L. Houben, J. Coenjaerts, L. Kimpen, W. Hofland, F. Schellevis, J. Bont, "Detection of multiple respiratory pathogens during primary respiratory infection: nasal swab versus nasopharyngeal aspirate using realtime polymerase chain reaction", European journal of clinical microbiology \& infectious diseases, Vol. 29, no. 4, pp. 365-371, 2010. 
[56] T. Magrone, M. Magrone, E. Jirillo, "Focus on Receptors for Coronaviruses with Special Reference to Angiotensin-converting Enzyme 2 as a Potential Drug Target-A Perspective", Endocrine, Metabolic \& Immune Disorders Drug Targets, 2020.

[57] D. Vinayachandran, B. Saravanakarthikeyan, "Salivary diagnostics in COVID-19: Future research implications", Journal of Dental Sciences, 2020.

[58] I. Hamming, W. Timens, L. Bulthuis, T. Lely, G. Navis, H. van Goor, "Tissue distribution of ACE2 protein, the functional receptor for SARS coronavirus. A first step in understanding SARS pathogenesis", Journal of Pathology, Vol. 203, no. 2, pp. 631-637, 2004.

[59] C. Jasper, y. Cyril, T. Kelvin, "Improved molecular diagnosis of COVID-19 by the novel, highly sensitive and specific COVID-19-RdRp/Hel real-time reverse transcription-PCR assay validated in vitro and with clinical specimens", Journal of Clinical Microbiology, Vol. 58, no. e00310-20, 2020. 